\title{
UPAYA MENINGKATKAN DISIPLIN GURU DALAM KEHADIRAN MENGAJAR DI KELAS MELALUI PENERAPAN REWARD AND PUNISHMENT DI SD NEGERI O2 NANGA JETAK KECAMATAN DEDAI KABUPATEN SINTANG
}

\author{
Rosiana \\ SD Negeri 02 Nanga Jetak, Dinas Pendidikan Kabupaten Sintang \\ E-mail: rosianajetak@gmail.com
}

\begin{abstract}
The purpose of this research is to find alternative problem solving as an effort to improve teacher discipline in teaching presence in the classroom through the application of Reward and Punishment. The method used in this study is the School Action Research (PTS) method. The approach used in this action research is a qualitative approach. This school action research activity consists of several stages, namely: (1) Planning (2) Implementation (3) Observation (4) Reflection. The study was conducted at 02 Nanga Jetak Elementary School, Dedai District, Sintang Regency. This class action research was conducted on October 8, 2019 until October 30, 2019. Data collection techniques from school action research is through qualitative data obtained from observations, observations, and interviews. The research instruments used in this school action research include: (1) Rating Scale (2) Observation Sheet (3) Questionnaire. Analysis of the data used in this study is the analysis of qualitative data sourced from primary and empirical data. From the results of this study, it can be concluded that to improve teacher discipline in class attendance at teaching and learning activities can be done by applying Reward and Punishment to teachers.
\end{abstract}

Keywords: Discipline, Teaching Presence, Reward, Punishment 


\begin{abstract}
Abstrak
Tujuan dari penelitian ini adalah ingin mencari alternatif pemecahan masalah sebagai upaya meningkatkan disiplin guru dalam kehadiran mengajar di kelas melalui penerapan Reward and Punishment. Metode yang digunakan dalam penelitian ini adalah metode Penelitian Tindakan Sekolah (PTS). Pendekatan yang digunakan dalam penelitian tindakan ini ialah pendekatan kualitatif. Kegiatan penelitian tindakan sekolah ini, terdiri atas beberapa tahap, yaitu : (1) Perencanaan (2) Pelaksanaan (3) Pengamatan (4) Refleksi. Penelitian dilaksanakan di SD Negeri 02 Nanga Jetak Kecamatan Dedai Kabupaten Sintang. Penelitian tindakan kelas ini dilaksanakan pada 08 Oktober 2019 s.d. 30 Oktober 2019. Teknik pengumpulan data dari penelitian tindakan sekolah ini adalah melalui data kualitatif yang diperoleh dari observasi, pengamatan, maupun wawancara. Instrumen penelitian yang digunakan dalam penelitian tindakan sekolah ini antara lain adalah : (1) Skala Penilaian (2) Lembar Pengamatan (3) Angket. Analisa data yang digunakan dalam penelitian ini adalah analisa data kualitatif yang bersumber dari data primer maupun empiris. Dari hasil penelitian ini, dapat disimpulkan bahwa untuk meningkatkan disiplin guru dalam kehadiran dikelas pada kegiatan belajar mengajar dapat dilakukan dengan penerapan Reward and Punishment kepada guru.
\end{abstract}

Kata Kunci: Disiplin, Kehadiran Mengajar, Reward, Punishment 


\section{A. Pendahuluan}

Usaha meningkatkan mutu pendidikan sesuai dengan cita-cita bangsa Indonesia, untuk mewujudkan kesejahteraan umum dan mencerdaskan kehidupan bangsa, di mana pendidikan mempunyai peranan penting dalam meningkatkan ketakwaan kepada Tuhan Yang Maha Esa, kecerdasan, dan ketrampilan.

\section{Untuk melaksanakan tugas} dalam meningkatkan mutu pendidikan maka diadakan proses belajar mengajar, guru merupakan figur sentral, di tangan gurulah terletak kemungkinan berhasil atau tidaknya pencapaian tujuan belajar mengajar di sekolah. Oleh karena itu tugas dan peran guru bukan saja mendidik, mengajar dan melatih tetapi juga bagaimana guru dapat membaca situasi kelas dan kondisi dan kondisi siswanya dalam menerima pelajaran.

Untuk meningkatkan peranan guru dalam proses belajar mengajar dan hasil belajar siswa, maka guru diharapkan mampu menciptakan lingkungan belajar yang efektif dan akan mampu mengelola kelas. Guru adalah pendidik profesional dengan tugas utama mendidik dan mengevaluasi peserta didik, pada pendidikan anak usia dini jalur pendidikan formal, pendidikan dasar dan pendidikan menengah. Sementara pegawai dunia pendidikan merupakan bagian dari tenaga kependidikan, yaitu anggota masyarakat yang mengabdikan diri dan diangkat untuk menunjang penyelenggaraan pendidikan. Dalam informasi tentang wawasan Wiyatamandala, kedisiplinan guru diartikan sebagai sikap mental yang mengandung kerelaan mematuhi semua ketentuan, peraturan dan norma yang berlaku dalam menunaikan tugas dan tangung jawab.

Dari pengertian diatas dapat disimpulkan, kedisiplinan guru dan pegawai adalah sikap penuh kerelaan dalam mematuhi semua aturan dan norma yang ada dalam menjalankan tugasnya sebagai bentuk tanggung jawabnya terhadap pendidikan anak didiknya. Karena bagaimana pun seorang guru atau tenaga kependidikan (pegawai), merupakan 
cermin bagi anak didiknya dalam sikap atau teladan, dan sikap disiplin guru dan tenaga kependidikan (pegawai) akan memberikan warna terhadap hasil pendidikan yang jauh lebih baik.

Keberhasilan proses pembelajaran sangat bergantung pada beberapa faktor diantaranya adalah faktor guru. Guru sangat memegang peranan penting dalam keberhasilan proses pembelajaran. Guru yang mempunyai kompetensi yang baik tentunya akan sangat mendukung keberhasilan proses pembelajaran.

Peranan guru selain sebagai seorang pengajar, guru juga berperan sebagai seorang pendidik. Pendidik adalah seiap orang yang dengan sengaja mempengaruhi orang lain untuk mencapai tingkat kemanusiaan yang lebih tinggi (Sutari Imam Barnado, 1989:44). Sehinggga sebagai pendidik, seorang guru harus memiliki kesadaran atau merasa mempunyai tugas dan kewajiban untuk mendidik. Tugas mendidik adalah tugas yang amat mulia atas dasar "panggilan" yang teramat suci. Sebagai komponen sentral dalam sistem pendidikan, pendidik mempunyai peran utama dalam membangun fondamen-fondamen hari depan corak kemanusiaan. Corak kemanusiaan yang dibangun dalam rangka pembangunan nasional kita adalah "manusia Indonesia seutuhnya", yaitu manusia yang beriman dan bertaqwa kepada

Tuhan Yang Maha Esa, percaya diri disiplin, bermoral dan bertanggung jawab. Untuk mewujudkan hal itu, keteladanan dari seorang guru sebagai pendidik sangat dibutuhkan.

Keteladanan guru dapat dilihat dari prilaku guru sehari-hari baik didalam sekolah maupun diluar sekolah. Selain keteladanan guru, kedisiplinan guru juga menjadi salah satu hal penting yang harus dimiliki oleh guru sebagai seorang pengajar dan pendidik.

Fakta dilapangan yang sering kita jumpai disekolah adalah kurang disiplinnya guru, terutama masalah disiplin guru masuk kedalam kelas pada saat kegiatan pembelajaran dikelas.

Berdasarkan uraian diatas, penulis tertarik untuk melakukan 
penelitian tindakan sekolah dengan judul : "Upaya Meningkatkan Disiplin Guru dalam Kehadiran Mengajar Dikelas Melalui penerapan Reward and Punishment di SD Negeri 02 Nanga Jetak Kecamatan Dedai Kabupaten Sintang".

\section{B. Metode}

Metode yang digunakan dalam penelitian ini adalah metode Penelitian Tindakan Sekolah (PTS). Pendekatan yang digunakan dalam penelitian tindakan ini ialah pendekatan kualitatif. Kegiatan penelitian tindakan sekolah ini, terdiri atas beberapa tahap, yaitu : (1)

Perencanaan (2) Pelaksanaan (3) Pengamatan (4) Refleksi.

Penelitian dilaksanakan di SD Negeri 02 Nanga Jetak Kecamatan Dedai Kabupaten Sintang. Penelitian tindakan kelas ini dilaksanakan pada 08 Oktober 2019 s.d. 30 Oktober 2019.

Teknik pengumpulan data dari penelitian tindakan sekolah ini adalah melalui data kualitatif yang diperoleh dari observasi, pengamatan, maupun wawancara. Instrumen penelitian yang digunakan dalam penelitian tindakan sekolah ini antara lain adalah : (1) Skala Penilaian (2) Lembar Pengamatan (3) Angket. Analisa data yang digunakan dalam penelitian ini adalah analisa data kualitatif yang bersumber dari data primer maupun empiris.

\section{Pembahasan Dan Hasil}

Penelitian Tindakan Sekolah (PTS) ini dilaksanakan dalam dua siklus. Hali ini dikarenakan keterbatasan waktu yang tersedia, serta dengan dua siklus sudah penulis anggap cukup untuk peningkatan disiplin guru dalam kehadiran dikelas pada kegiatan belajar mengajar.

Siklus 1

Siklus 1 terdiri atas beberapa tahap, yaitu : (1) Perencanaan, (2) Pelaksanaan, (3) Pengamatan dan Evaluasi, dan (4) Refleksi.

1. Perencanaan

Perencanaan adalah langkah awal yang dilakukan oleh penulis saat akan memulai tindakan. Agar perencanaan mudah dipahami dan dilaksanakan oleh penulis yang akan melakukan tindakan, maka penulis 
membuat rencana tindakan sebagai berikut :

(a) Merumusan masalah yang akan dicari solusinya. Dalam penelitian ini masalah yang akan dicari solusinya adalah masih banyaknya guru yang kurang disiplin dalam kehadiran dikelas pada proses belajar mengajar.

(b) Merumusan tujuan penyelesaian masalah/tujuan menghadapi tantangan/tujuan melakukan inovasi/tindakan. Dalam penelitian ini penulis mengambil rencana untuk melakukan tindakan memberikan Reward dan Punishment kepada guru- guru untuk meningkatkan kedisiplinan guru dalam kehadiran dikelas pada proses belajar mengajar.

(c) Merumusan indikator keberhasilan penerapan Reward dan Punishment dalam meningkatkan disiplin guru dalam kehadiran dikelas pada proses belajar mengajar. Indikator keberhasilan penerapan tindakan ini penulis tetapkan sebesar $75 \%$, artinya tindakan ini dinyatakan berhasil bila $75 \%$ guru tidak terlambat masuk kelas dalam proses pembelajaran. (d) Merumusan langkah-langkah kegiatan penyelesaian masalah atau kegiatan menghadapi tantangan atau kegiatan melakukan tindakan.

Langkah-langkah yang diambil penulis dalam melakukan tindakan antara lain adalah melakukan sosialisasi kepada para guru mengenai penelitian yang akan dilaksanakan, serta menyampaikan tujuan dari penerapan tindakan yang dilakukan oleh penulis.

Kepada para guru disampaikan mengenai penerapan Reward dan Punishment yang akan diterapkan dalam penelitian ini. Pada siklus pertama ini, akan dipampang atau ditempel diruang guru, maupun diruang $\mathrm{TU}$, peringkat nama-nama guru yang paling rendah tingkat keterlambatan masuk kelasnya sampai yang paling tinggi tingkat keterlambatannya.

(e) Mengidentifikasi warga sekolah dan atau pihak-pihak terkait lainnya yang terlibat dalam penyelesaian masalah/menghadapi tantangan atau melakukan tindakan. Penulis melakukan identifikasi siapa saja yang dilibatkan dalam penelitian ini. Pihak-pihak yang dilibatkan 
dalam penelitian ini adalah : guru, guru piket, TU, dan siswa.

(f) Mengidentifikasi metode pengumpulan data yang akan digunakan.

Metode pengumpulan data yang diambil oleh penulis merupakan data kualitatif melalui observasi, pengamatan serta wawancara kepada siswa mengenai kehadiran guru dikelas pada kegiatan belajar mengajar.

(g) Penyusunan instrumen pengamatan dan evaluasi.

Dalam pengambilan data, penulis menggunakan instrument berupa lembar observasi atau pengamatan, skala penilaian serta angket yang disebarkan kepada siswa, untuk mengetahui penilaian dari siswa mengenai tingkat kehadiran guru dikelas dalam proses kegiatan belajar mengajar.

(h) Mengidenifikasi fasilitas yang diperlukan.

Fasilitas atau alat bantu yang digunakan dalam penelitian ini antara lain : kertas (lembar pengamatan), alat tulis berupa balpoin, serta jam dinding yang ada disetiap kelas, serta rekap jumlah kehadiran dari setiap guru.

2. Pelaksanaan

Pelaksanaan penelitian tindakan sekolah ini dilaksanakan melalui beberapa kegiatan, antara lain :

(a) Menyebarkan lembar pengamatan kepada setiap Ketua Kelas atau Sekretaris kelas sebanyak 12 set, sesuai dengan banyaknya jumlah rombongan belajar di SD Negeri 02 Nanga Jetak Kecamatan Dedai Kabupaten Sintang sebanyak 12 rombongan belajar. Dalam lembar pengamatan itu, telah dibuat daftar guru yang mengajar dikelas itu setiap jam dan diberi kolom jam masuk kelas serta jam keluar kelas. Lembar pengamatan dapat dilihat pada lampiran.

(b) Berkoordinasi dengan petugas piket yang setiap hari terdiri dari 2 orang petugas, yaitu dari guru yang tidak mempunyai jam mengajar pada hari itu dan satu orang dari tata usaha. Petugas piket akan mengedarkan daftar hadir guru dikelas yang telah dibuat agar dapat melihat tingkat kehadiran guru disetiap kelas dan disetiap pergantian jam pelajaran. Guru yang terlambat 
lebih dari 15 menit, dianggap tidak hadir dan diberi tanda silang. Daftar hadir guru dapat dilihat dalam lampiran.

(c) Setelah selesai jam pelajaran, dilakukan rekapitulasi dari hasil pengamatan, baik dari guru piket, dari siswa maupun dari penulis.

(d) Kegiatan tersebut dilakukan terus setiap hari kepada setiap guru selama satu minggu (satu siklus).

3. Pengamatan dan Evaluasi

Pengamatan atau observasi dilakukan oleh peneliti dengan menggunakan lembar observasi selama satu minggu (satu siklus), untuk semua guru yang berjumlah 23 orang. Selama pengamatan peneliti

Tabel 1, Rekapitulasi Tingkat Keterlambatan Guru Pada Kehadiran di Kelas Siklus I

\begin{tabular}{|c|c|c|}
\hline \multicolumn{3}{|c|}{ Waktu Keterlambatan/Jumlah/Prosentase } \\
\hline Kurang dari 10 Menit & 10 Menit s.d. 15 Menit & Lebih dari 15 Menit \\
\hline 5 & 7 & 11 \\
\hline $21,74 \%$ & $30,43 \%$ & $47,83 \%$ \\
\hline
\end{tabular}

Dari hasil

rekapitulasi tingkat keterlambatan guru dikelas pada proses pembelajaran diperoleh data, dibantu atau berkolaborasi dengan guru piket. Pengamatan oleh peneliti meliputi :

(a) Kehadiran guru dikelas

(b) Tingkat keterlambatan guru masuk kelas

(c) Waktu meninggalkan kelas setelah selesai pelajaran

Peneliti juga melakukan penilaian dari hasil lembar observasi yang dibagikan kepada pengurus kelas untuk mengamati kehadiran guru dikelas.

Dari hasil pengamatan serta rekap dari tingkat kehadiran guru dikelas pada proses belajar mengajar dapat dilihat pada tabel berikut : 
dengan 15 menit, dan 11 orang

Untuk lebih jelasnya dapat guru terlambat masuk kelas lebih digambarkan pada grafik dibawah ini : dari 15 menit.

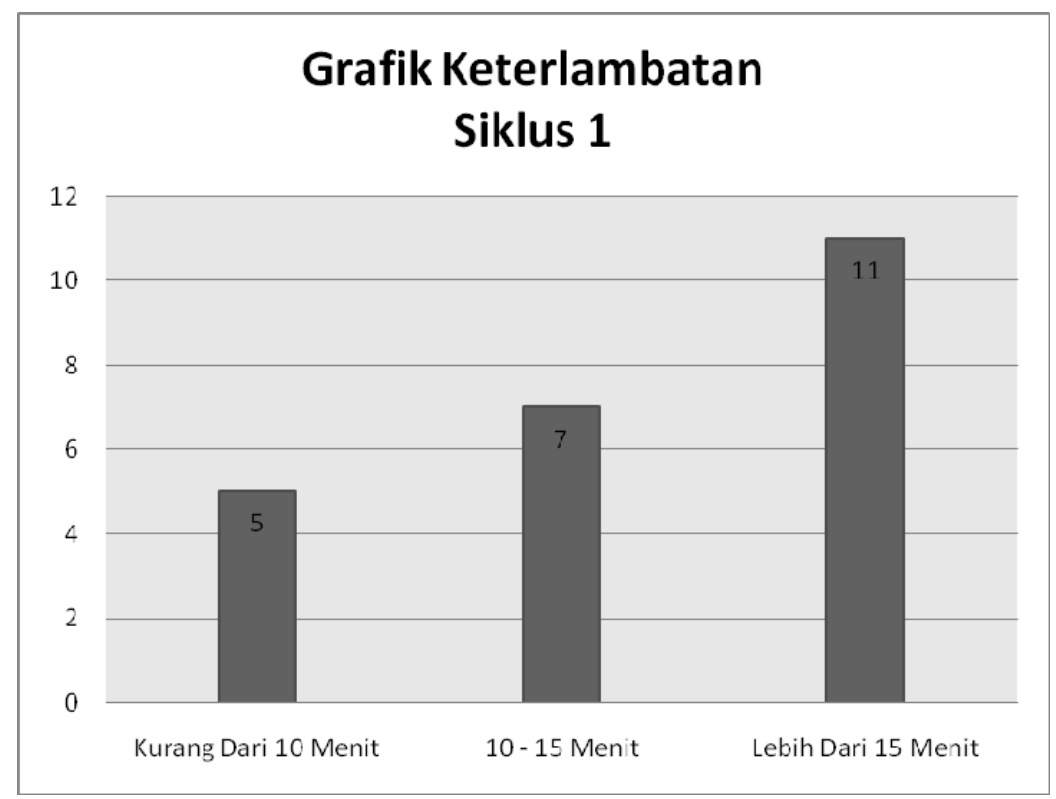

Grafik 1. Grafik Keterlambatan

Dari data diatas dapat ditarik kesimpulan bahwa tingkat keterlambatan guru masuk kelas lebih dari 15 menit pada proses kegiatan belajar mengajar masih tinggi yaitu 11 orang atau 47,83 $\%$. Berdasarkan indicator yang telah ditetapkan bahwa keberhasilan tindakan ini adalah $75 \%$, atau bila $75 \%$ guru tidak terlambat lebih dari 10 menit. Pada siklus pertama ini guru yang tidak terlambat lebih dari 10 menit baru $21,74 \%$, jadi peneliti berkesimpulan harus diadakan penelitian atau tindakan lagi pada siklus berikutnya atau siklus kedua.

\section{Refleksi}

Setelah selesai satu siklus maka diadakan refleksi mengenai kelemahan atau kekurangan dari pelaksanaan tindakan pada siklus pertama.

Refleksi dilaksanakan bersamasama kolaborator untuk menentukan tindakan perbaikan pada siklus berikutnya. Dari hasil refleksi dapat diambil suatu kesimpulan bahwa perlu penerapan Reward dan Punishment yang lebih tegas lagi daripada siklus pertama.

Siklus 2

Siklus 2 terdiri atas beberapa tahap, sama seperti siklus 1 yaitu 
Perencanaan, (2) Pelaksanaan, (3)

Pengamatan dan Evaluasi, dan (4)

Refleksi.

1. Perencanaan

Dari hasil refleksi pada siklus pertama, peneliti merencanakan untuk melakukan tindakan Reward dan Punishment yang lebih tegas dibandingkan dengan siklus pertama.

Peneliti merencanakan untuk mengumumkan hasil observasi mengenai tingkat keterlambatan guru masuk kelas dalam proses belajar mengajar, pada kegiatan upacara bendera hari Senin. Hal ini terlebih dahulu disosialisasikan kepada semua guru pada saat refleksi siklus pertama.

2. Pelaksanaan

Pelaksanaan penelitian tindakan sekolah pada siklus yang kedua ini dilaksanakan melalui beberapa kegiatan, antara lain :

(a) Menyebarkan lembar pengamatan kepada setiap Ketua Kelas atau Sekretaris kelas sebanyak 12 set, sesuai dengan banyaknya jumlah rombongan belajar di SD Negeri 02 Nanga Jetak Kecamatan Dedai Kabupaten Sintang sebanyak 12 rombongan belajar. Dalam lembar pengamatan itu, telah dibuat daftar guru yang mengajar dikelas itu setiap jam dan diberi kolom jam masuk kelas serta jam keluar kelas. Lembar pengamatan dapat dilihat pada lampiran.

(b) Berkoordinasi dengan petugas piket yang setiap hari terdiri dari 2 orang petugas, yaitu dari guru yang tidak mempunyai jam mengajar pada hari itu dan satu orang dari tata usaha. Petugas piket akan mengedarkan daftar hadir guru dikelas yang telah dibuat agar dapat melihat tingkat kehadiran guru disetiap kelas dan disetiap pergantian jam pelajaran. Guru yang terlambat lebih dari 15 menit, dianggap tidak hadir dan diberi tanda silang. Daftar hadir guru dapat dilihat dalam lampiran.

(c) Setelah selesai jam pelajaran, dilakukan rekapitulasi dari hasil pengamatan, baik dari guru piket, dari siswa maupun dari penulis.

Kegiatan tersebut dilakukan terus setiap hari kepada setiap guru selama satu minggu (satu siklus) pada siklus kedua

3. Pengamatan dan Evaluasi

Pengamatan atau observasi dilakukan oleh peneliti dengan menggunakan lembar observasi selama satu minggu (satu siklus), untuk semua guru yang berjumlah 23 orang. Selama pengamatan peneliti dibantu atau berkolaborasi dengan guru piket. Pengamatan oleh peneliti meliputi :

(d) Kehadiran guru dikelas 
(e) Tingkat keterlambatan guru masuk kelas

(f) Waktu meninggalkan kelas setelah selesai pelajaran

Peneliti juga melakukan penilaian dari hasil lembar observasi yang dibagikan kepada pengurus kelas untuk mengamati kehadiran guru dikelas.

Dari hasil pengamatan serta rekap dari tingkat kehadiran guru dikelas pada proses belajar mengajar pada siklus kedua dapat dilihat pada tabel berikut :

Tabel 2. Rekapitulasi Tingkat Keterlambatan Guru Pada Kehadiran di Kelas Siklus II

\begin{tabular}{|c|c|c|}
\hline \multicolumn{3}{|c|}{ Waktu Keterlambatan/Jumlah/Prosentase } \\
\hline Kurang dari 10 Menit & 10 Menit s.d. 15 Menit & Lebih dari 15 Menit \\
\hline 18 & 5 & 0 \\
\hline $78,26 \%$ & $21,74 \%$ & $0,00 \%$ \\
\hline
\end{tabular}

Dari hasil rekapitulasi tingkat keterlambatan guru dikelas pada proses pembelajaran diperoleh data, sebanyak 18 orang guru terlambat masuk kelas kurang dari 10 menit, 5 orang guru terlambat masuk kelas 10 menit sampai dengan 15 menit, dan tidak ada satu orangpun guru yang terlambat masuk kelas lebih dari 15 menit.

Untuk lebih jelasnya, tingkat keterlambatan guru masuk kelas pada proses belajar mengajar pada siklus kedua ini dapat digambarkan pada grafik dibawah ini : 


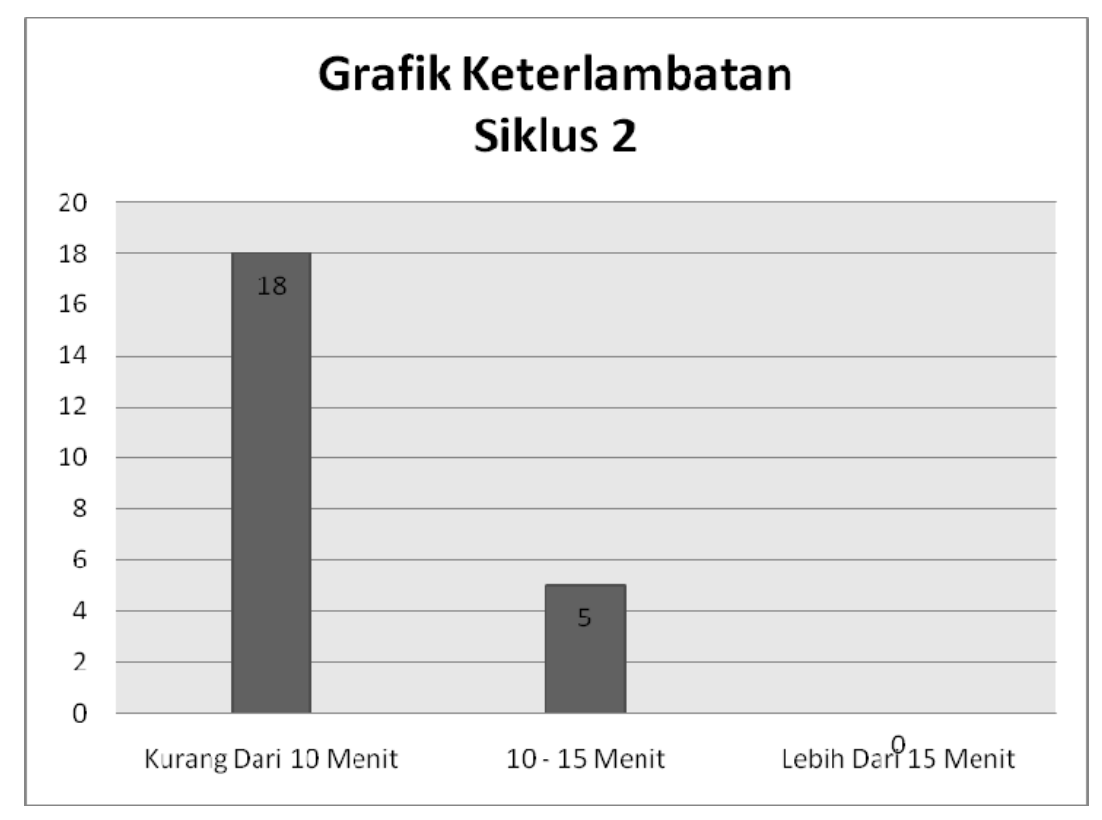

Grafik 2. Grafik Keterlambatan Siklus II

Dari hasil observasi pada siklus pertama dan siklus kedua dapat dilihat ada penurunan tingkat keterlambatan guru dikelas pada kegiatan belajar mengajar, atau terdapat peningkatan kehadiran guru dikelas.

\section{Refleksi}

Setelah selesai pelaksanaan tindakan pada siklus kedua maka diadakan refleksi mengenai kelemahan atau kekurangan dari pelaksanaan tindakan pada siklus kedua tersebut.

Dari hasil observasi dan data yang diperoleh, peneliti mengambil kesimpulan bahwa tindakan yang dilaksanakan pada siklus kedua dinyatakan berhasil, karena terdapat $78,26 \%$ guru yang terlambat kurang dari 10 menit, atau melebihi target yang telah ditentukan sebesar $75 \%$.

\section{Simpulan}

Berdasarkan analisis data, dari penelitian ini dapat ditarik kesimpulan bahwa penerapan Reward dan Punishment efektif untuk meningkatkan disiplin kehadiran guru dikelas pada kegiatan belajar mengajar.

Data yang diperoleh menunjukan bahwa setelah diadakan penerapan tindakan berupa Reward dan Punishment, guru yang terlambat lebih dari 15 menit adalah 0, dan guru yang terlambat kurang dari 10 menit sebanyak 18 orang guru. Penerapan Reward dan Punishment dapat meningkat disiplin guru hadir didalam kelas pada kegiatan belajar mengajar di SD Negeri 02 Nanga Jetak Kecamatan Dedai Kabupaten Sintang.

Karena adanya pengaruh positif Penerapan Reward dan Punishment 
terhadap disiplin guru hadir didalam kelas pada kegiatan belajar mengajar, maka melalui kesempatan ini penulis mengajukan beberapa saran : (1) Semua Kepada Kepala Sekolah disarakan melakukan Penerapan Reward dan Punishment untuk meningkatkan disiplin guru hadir didalam kelas pada kegiatan belajar mengajar di sekolah. (2) Kepada semua guru dalam melaksanakan tugas untuk dapat meningkatkan disiplin dalam kehadiran dikelas sebagai bentuk pelayanan minimal kepada peserta didik di sekolah.

\section{Daftar Pustaka}

Akhmad Sudrajat, (2010) Manfaat Prinsip dan Asas Pengembangan Budaya Sekolah. [On Line]. Tersedia : http://akhmadsudrajat.wordpress.co $\mathrm{m} / 2010 / 03 / 04 /$ manfaat- prinsip-danasas-pengembangan-budaya-sekolah/ [06 Oktober 2010].

Amstrong. Michael, (1991). Manajemen Sumber Daya Manusia. Jakrta:Ghalia Indonesia

Anwar Prabu Mangkunegara. (1994). Psikologi Perusahaan. Bandung:PT. Trigenda.

Anwar Prabu Mangkunegara (2000). Manajemen Sumber Daya Manusia Perusahaan. Bandung : Penerbit Remaja Rosdakarya.

Arikunto, S. (2002). Prosedur Penelitian Suatu Pendekatan Praktek. Jakarta:Rineka Cipta.
Aunurrahman. (2009). Belajar dan Pembelajaran. Bandung:Alfabeta.

Bambang Nugroho. (2006). Reward dan Punishment. Bulletin CiptaKarya Departemen Pekerjaan Umum Edisi No. 6/IV/Juni 2006.

Departemen Pendidikan Nasional. (2003). Undang-undang Nomor 20 Tahun 2003 Tentang Sistem Pendidikan Nasional. Jakarta:Depdiknas.

Hidayat, Sucherli. (1986). Peningkatan Produktivitas Organisasi dan Pegawai Negeri Sipil: Kasus Indonesia, Jakarta:Prisma.

Megawangi, Ratna. (2007). Membangun SDM Indonesia Melalui Pendidikan Holistik Berbasis Karakter. Jakarta:Indonesian Heritage Foundation.

Sanjaya, W. (2008). Kurikulum dan Pembelajaran. Teori dan Praktik Pengembangan Kurikulum Tingkat Satuan Pendidikan (KTSP). Jakarta:Kencana Prenada Media Group.

Subagio. (2010) Kompetensi Guru dalam Meningkatkan Mutu Pembelajaran [On Line]. Tersedia : http://subagiosubagio.blogspot.com/2010/03/komp etensi-guru-dalam- meningkatkanmutu.html.

Syamsul Hadi, (2009). Kepemimpinan Pembelajaran, Makalah Disampaikan pada Sosialisasi Akuntabilitas Kinerja Kepala Sekolah Dalam Inovasi Pembelajaran. Departemen Pendidikan Nasional, Direktorat Jenderal Peningkatan Mutu Pendidik dan Tenaga Kependidikan, Direktorat Tenaga Kependidikan 